How to Cite

Putra, K. S. A. (2018). Epidemiology of rabies. International Journal of Chemical \& Material Sciences, 1(1), 14-24.

https://doi.org/10.31295/ijcms.v1n1.4

\title{
Epidemiology of Rabies
}

\author{
Ketut Santhia Adhy Putra \\ Independent Research of Zoonotic Diseases Ex. coordinator of Virology Laboratory, BBVet Denpasar, Indonesia \\ Directorate General of Livestock and Animal Health, Ministry of Agriculture, Jakarta, Indonesia \\ Email: santhia.adhyputra@yahoo.co.id / sandhytra30@yahoo.com
}

\begin{abstract}
The occurrence of an outbreak of rabies in Bali as a shock to the people and local governments are instantly becoming the world's attention because of Bali as a world tourism destination. Since the first outbreak in the southern peninsula of Bali in November 2008, rabies quickly spread across the districts/municipality, until July 2015 had spread across 54 subdistricts and 263 villages. The proportion of rabies cases in the subdistricts and villages the highest occurred in 2011 is shown $94.7 \%$ and $36.7 \%$, respectively, but its spread dropped dramatically in 2013 only occurred in 23 subdistricts (40.4\%) and 38 villages (4,2\%), though rabies outbreak back by increasing the number and distribution of rabies cases significantly in 2014, spread over 94 villages even until July 2015 spread over 89 villages. Rabies attacks the various breeds of dogs with the proportion of rabies in the local dogs showed the highest (98.44\%), as well as the male dog, is very significantly higher than female dogs. By age group, the proportion seen in the age group of 1 to 2 years showed the highest (39.9\%). Other animals, such as cats, cows, goats, and pigs have also contracted the rabies infected dog bitesthe. The incidence of rabies is endemic tend to look at some of the same villages actively repeated every year, most occur in Bangli district (29 villages), nevertheless for 3 consecutive years there were 58 villages there are no cases of rabies. The increasing number of cases of rabies in Bali due to the increasing cases of dog bites, since May 2008 to July 2015, there were 274792 cases, an average of 34349 cases per year, or 95 cases per day, the highest occurred in 2010 (67 021 cases) with the proportion of positive rabies highest (34.92\%) as well as attack rate (AR) showed the most high (0.125\%). The number of rabies from 2008 to July 2015 as many as 1,157 cases of rabies and the positive opportunities of dog bite cases continue to rise even odds 83.07 times greater than the previous year. The average prevalence in Bali is showed $16.1 \%$, the highest in Karangasem district (26.1\%), but the proportion is highest seen in Bangli district (16.94\%). The increasing cases of dog bites there seem to be the influence of the season. It is seen that the number of cases of wild dogs bite or semi free-range dogs likely to increase following cycles of dogs breeding season, most occur in the dry season (April to November), except in 2008 most of the rainy season (December to March) were recorded 8 cases. It was concluded that rabies is endemic, the majority occurred in the local wild dog or semi-free-ranging dogs especially in breeding season and never yet vaccinated for rabies.
\end{abstract}

Keywords---animal, epidemiology, rabies virus.

\section{Introduction}

Bali Provincial initially historically as a rabies-free area but since 2008 rabies outbreak and status changes as infected areas that contribute to increasing the number of infected areas in Indonesia to 24 provinces. Bali province is divided into 9 districts/municipality and is composed of 57 subdistricts and 716 villages with a total population of 4.05627 million. The population density / $\mathrm{km} 2$ followed by the dog population density is high. The ratio of the dog population and the population in Badung is, 1: 8.27 (Putra et al., 2011) assumed to be the same as in the districts/municipality in Bali so it can be assumed also the number of dogs in Bali at around 490480 to 507033 . Dogs as God's creatures have a life in harmony with the human environment. Ecology or behavior of the dog should be understood as a social animal who has a strong inherent desire to interact with their social group, including members of the human family (Wells, 2004). Strong social bonds and hyper-entanglement between the dog and its owner (McCrave, 1991; Takeuchi et al., 2000) can be demonstrated by the behavior of a spoiled, maintain and protect and

ISSN 2632-9468

Received Jan 10, 2018 / Accepted Jun 20, 2018 / Published Jul 05, 2018 
have a fairly high degree of intelligence comply. If the dog is separated from and/or deny access to their owners, the behavior occurs anxiety, fear, distress, frustration and panic (Linsay, 2001; Flanning \& Dodman, 2001). Dogs can also change the behavior in case of disharmony relationship between humans and dogs, as there is the treatment of physical violence against the dog so that the memory of violence will always be attached to him. When the same person is close to or passes through its territory into the area or master's house then he will be very fierce and attack him. The relationship between dogs and humans need each other. Dogs need humans because it can give life and love, while these animals because humans need to maintain and protect it. Even in Bali, dogs (blang bungkem) is believed to have a high spiritual value is often used as an offering at a religious ceremony that is believed to cleanse the natural environment with a noble goal is to return to the natural elements, while the eternal soul for the improved degree. The use of dogs as an animal sacrifice with spiritual treatment can also be defined to maintain the balance of the dog population. Therefore, the harmonization of human life, animals and other living beings and the natural environment is important. When harmony is ignored due to various reasons that arise is to destroy each other. When an outbreak of rabies in Bali is one example as to cause the disharmony that relationship because there are measures to prevent the spread of rabies elimination. Rabies is known as one of the zoonotic infectious diseases, including the list of B Office international des Epizooties (OIE) and WHO establish rabies ranking 12 deadly diseases (Meslin \& Stohr, 1997). The outbreak of Rabies can affect the socio-economic and public health. Animals or humans afflicted with rabies is characterized by progressive encephalomyelitis and acute ends with death (Mudhusudana \& Sukumaran, 2008), with an incubation period of up to cause death vary widely. In animals, lasts 2 months with a range from two weeks to several months or a year (Frymus et al., 2009), whereas in humans, an average of 1-3 months with a range of 5 days to more than a year (Warrel \& Warrel, 2004). Rabies is caused by Lyssavirus genotype 1 of the family Rhabdoviridae (Nadin-Davis et al., 2008) and is transmitted through the bite of an animal rabies (Claviland et al., 2006), especially dogs that generally occur in the countries of Africa, Latin America and Asia (Coetzee \& Neil, 2007), whereas that is transmitted by various species of wild animals, such as wolves, raccoons, skunks, foxes and bath happening in Europe, North America and Africa (McElhinney et al., 2008). Ecologically cycle of transmission of rabies by a dog called urban rabies, while the so-called wild animal rabies sylvatic (Swanepoel, 2005; McElhinney et al., 2008). Victims of rabies due to a dog bite in Indonesia during the period from 2009 through 2013 listed 835 people, the highest occurred in Bali in 2008 until July 2015, 161 individuals (Ketut Santhia \& Wayan Sudiasa, 2015).

Control efforts have been made, but the bite cases continue to increase along with the growing number of dog rabies which at any moment could threaten public health. The purpose of this study was to determine the epidemiology of rabies in animals in Bali that the results can be considered in the prevention, control, and eradication of rabies in Indonesia, especially in Bali.

\section{Research Method}

Rabies case data obtained from the Department of Animal Husbandry and Health of Bali Province, the Provincial Animal Health Laboratory and BBVet Denpasar Bali from November 2008 to July 2015. The data consists of the distribution of the dog population, dog bite cases, race, age and sex of the dog contracting rabies. Cases tested positive for rabies according to the examination of brain samples from susceptible animals were then tested by fluorescent antibody technique [FAT). Data were analyzed using descriptive statistics Microsoft excel, graph pad software is primarily an analysis of the distribution, the proportion of cases, prevalence, incidence rate, case fatality rate, the odds ratio (OR), standard deviation (SD) and confidence intervals (Altman, 1991.1998; Daly, 1998).

\section{Results and Analysis}

\section{Distribution of Rabies}

First suspected cases of rabies occurred in Bali, with the outbreak of suspected rabid dog bites in Ungasan and Jimbaran Villages, subdistrict of South Kuta, Badung district. Victims of dog bites continue to rise, referred to hospitals in the district/city and Sanglah Hospital, Denpasar. Residents who were referred to the hospital and died after being treated a few days; Diagnosis set is encephalitis based on clinical symptoms and history of the dog ever bitten since July, September and October 2008. During the dog bite cases, no samples were taken for laboratory examination. While the dog bite cases continue to grow and its spread is also widespread. When a resident of the 
village of Ungasan, South Kuta referred to Sanglah Hospital on November 23, 2008, with a history of dog bites on 16 September 2008 which showed symptoms of rabies and died after being hospitalized a day. The sample was taken for examination RT-PCR positive results Rabies virus. But the dog bite sample of a newly acquired dog biting people in the village of Kedonganan, South Kuta subdistrict on November 26, 2008, and the results showed FAT positive for rabies virus. Since it is also designated as Bali rabies outbreak based on the Minister of Agriculture. No. 1637.1 / 2008 dated December 1, 2008. After that until December 2008, rabies has spread across four villages, namely Ungasan and Jimbaran, subdistrict of South Kuta, Legian village of Kuta subdistrict and Sesetan image of South Denpasar subdistrict. Even until June 2009, rabies has spread in six villages, namely the villages of Serangan (South Denpasar subdistrict), Pecatu, Tanjung Benoa (South Kuta subdistrict), Tuban, Kuta and Seminyak villages of Kuta subdistricts). Elimination action dog does when it affects the transfer of dogs by their owners to other districts so that rabies spread rapidly in districts/municipality in Bali. Until July 2015, the rabies has spread throughout the district / municipality, with a number of districts contracting rabies with a range of 3 to 54 sub-districts (SD. 17.36, 95\% CI. 11.47 to 36.52 ) and the number of villages infected with a range of 6 to 263 villages (SD. 94.30, 95\% CI 62.36 to 191, 93). The number of districts and villages infected with rabies continues to grow with the spread of the highest occurred in 2011, covering 54 subdistricts and 263 villages (Figure 1).

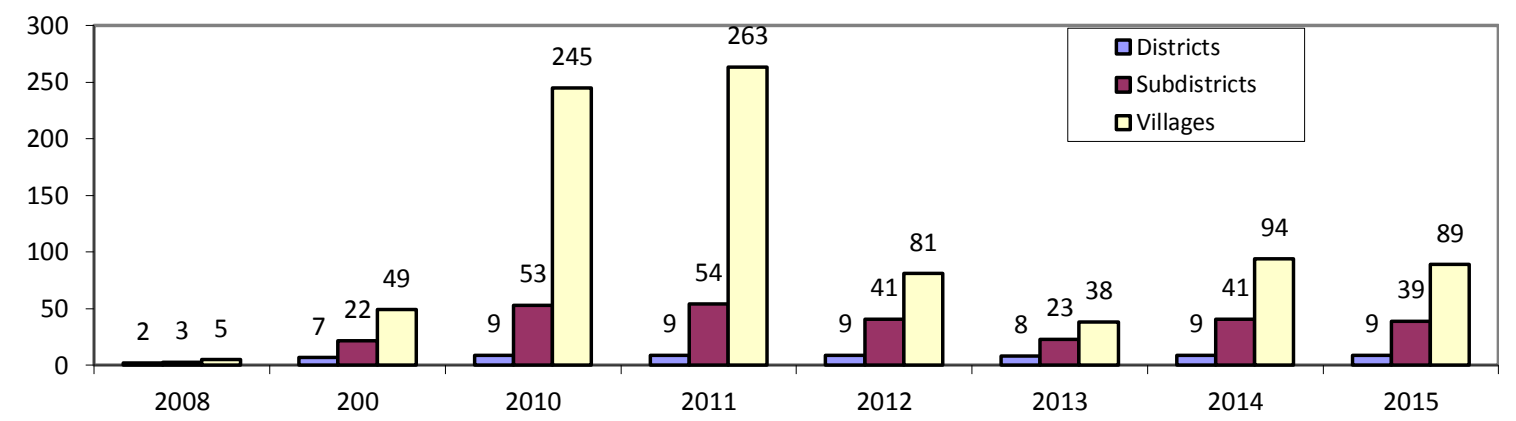

Figure 1. Distribution of positive rabies in each district, subdistricts, and villages of Bali Province

The proportion of rabies in the districts and villages the highest occurred in 2011 , respectively $94.7 \%$ and $36.7 \%$, after the distribution of cases decreased significantly in 2013 only occurred in 23 subdistricts $(40.4 \%)$ and 38 villages (4.2\%) or decreased respectively $59.6 \%$ and $31.8 \%$ than in 2011. the decline in the spread of rabies has been done due to mass vaccination in all districts/municipality in Bali. Nonetheless, because of vaccination coverage does not do a maximum of $100 \%$ of the entire of dogs population and then the dogs were not vaccinated are at high risk of contracting the rabies virus. Even the use of local strain vaccine efficacy is unclear, potentially increasing the spread of rabies. This is an apparent outbreak of rabies cases increased significantly in 2014, spread over 94 villages or increased 59.57\%, and even up to mid-2015 has spread in 89 villages (Figure 1). The proportion positive for rabies in animals in each district, sub-district and village highest seen in 2011, respectively $94.7 \%$ (95\% CI, 85.6 to 98.2 ) and $36.45 \%$ (95\% CI, 33, 3 40.3) (Table 1).

Table 1

The proportion of positive rabies in each subdistrict and villages since 2008 to 2015

\begin{tabular}{|c|c|c|c|c|c|c|}
\hline \multirow{2}{*}{ Years } & \multirow{2}{*}{$\begin{array}{l}\text { Subdistrics } \\
(\mathrm{n}=57)\end{array}$} & \multirow{2}{*}{$\begin{array}{l}\text { Villages } \\
(\mathrm{n}=716)\end{array}$} & \multicolumn{2}{|c|}{ Proporsion of cases / } & \multicolumn{2}{|c|}{ 95\% CI Proportion per } \\
\hline & & & Subdistricts & Villages & Subdistricts & Villages \\
\hline 2008 & 3 & 6 & 5,3 & 0,84 & $1,6-14,4$ & $0,4-1,8$ \\
\hline 2009 & 22 & 49 & 38,6 & 6,84 & $27,1-51,4$ & $5,2-8,5$ \\
\hline 2010 & 53 & 245 & 93,0 & 34,22 & $83,3-97,2$ & $30,8-37,8$ \\
\hline 2011 & 54 & 263 & 94,7 & 36,73 & $85,6-98,2$ & $33,3-40,3$ \\
\hline 2012 & 41 & 81 & 71,9 & 11,31 & $59,2-81,9$ & $9,2-13,8$ \\
\hline 2013 & 23 & 38 & 40,4 & 5,31 & $28,6-53,3$ & $3,7-7,2$ \\
\hline 2014 & 41 & 94 & 71,9 & 13,13 & $59,2-81,9$ & $10,9-15,8$ \\
\hline 2015 & 39 & 89 & 68,4 & 12,43 & $55,5-79,0$ & $10,2-15.1$ \\
\hline
\end{tabular}


The incidence of rabies in Bali is endemic, occurred throughout the year. From the data analysis of 2012 until July 2015 show a pattern of events in some villages the same happens over and over every year actively. Rabies cases that occur repeatedly in the same village are greatest in Bangli district (17 villages), but for three consecutive years in 58 villages there are no cases of rabies. Nevertheless, until July 2015, there are 104 villages that the possibility of contracting rabies infected villages increased repeatedly in the same villages (Graph 2)

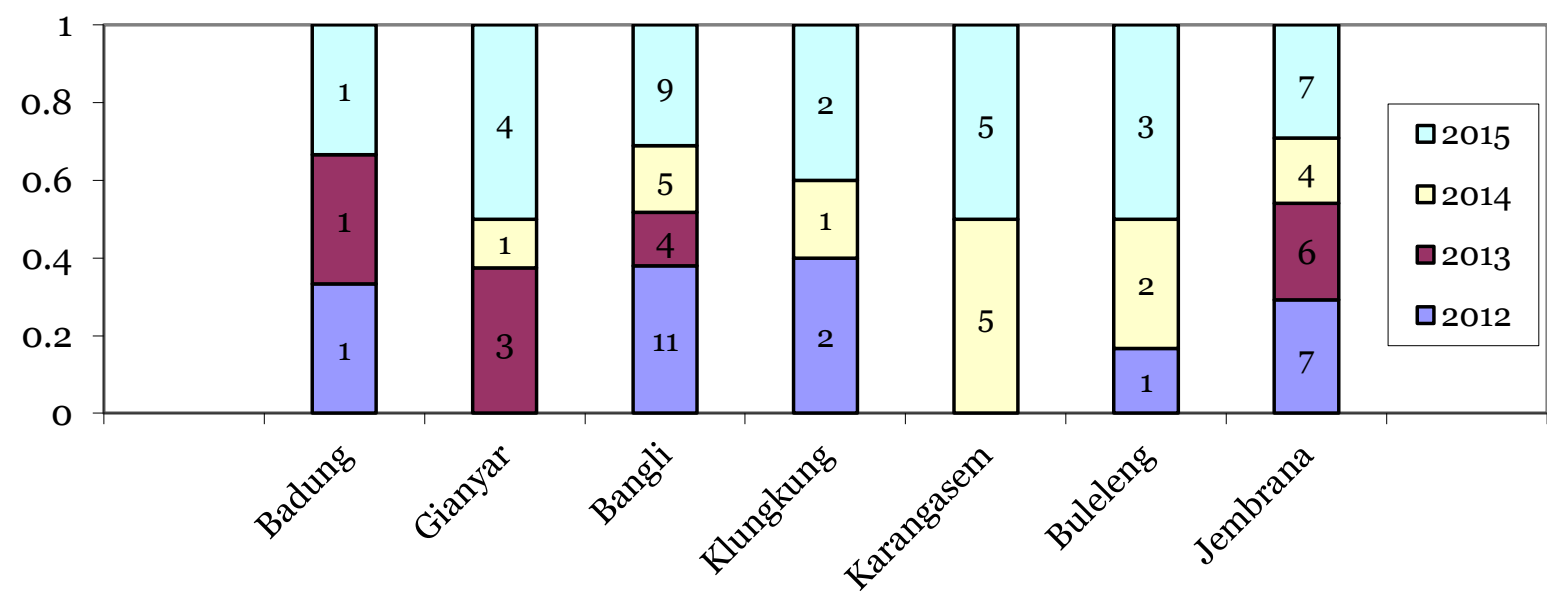

Graph. 2 Repeat rabies cases in the same village, 2012 to 2015

Widespread of rabies in Bali due to the increasing cases of dog bites, from May 2008 to July 2015, there were 274,792 cases, an average of 34,349 cases per year, or 95 cases per day. The frequency of dog bite cases is highest in 2010 (67,021 cases) with an average attack rate (AR), the highest $0.033 \%$ seen in $2010(0.125 \%)$. The results of FAT from brain sample of various animal species showed 1,157 samples (dogs, cats, cows, goats, and pigs) with a range of 7 to 404 samples positive for rabies (144.625 Mean, SD 131, 95, 95\% CI 87.34 to 268, 56) with the highest proportion of positive cases occurred in 2010, (34.92\%). The results of the analysis of odds ratios (OR) show the chances of positive cases of rabies bites the rabid dog in 2015, 83.07 times greater than the previous year with a range of confidence (confidence interval) $95 \%$ of the lowest 70.86 and the highest 97.39 (Table 2),

Table 2

Attack rate, Odd ratio and CI of positive rabies

\begin{tabular}{|c|c|c|c|c|c|c|c|}
\hline Years & $\begin{array}{l}\text { The } \\
\text { population of } \\
\text { susceptible } \\
\text { dogs }\end{array}$ & $\begin{array}{l}\text { Dogs } \\
\text { biting } \\
\text { cases }\end{array}$ & $\begin{array}{l}\text { Positive } \\
\text { rabies }\end{array}$ & $\begin{array}{l}\text { Proportion } \\
\text { positive } \\
\text { rabies }\end{array}$ & $\begin{array}{l}\text { Attack } \\
\text { rate } \\
(\%)\end{array}$ & $\begin{array}{l}\text { Odds } \\
\text { Ratio } \\
\text { (OR) }\end{array}$ & $\begin{array}{l}95 \% \text { Confident } \\
\text { Interval }(\mathrm{CI})\end{array}$ \\
\hline 2008 & 253.980 & 1.103 & 7 & 0,61 & 0,003 & 14,90 & $6,73-32,96$ \\
\hline 2009 & 287.300 & 21.805 & 81 & 7,0 & 0,028 & 28,17 & $22,02-36,06$ \\
\hline 2010 & 323.558 & 67.021 & 404 & 34,92 & 0,125 & 11,61 & $10,48-12,87$ \\
\hline 2011 & 431.720 & 52.798 & 90 & 7,78 & 0,021 & 14,77 & $11,84-18,43$ \\
\hline 2012 & 374.332 & 55.836 & 121 & 10,46 & 0,032 & 16,35 & $13,49-19,81$ \\
\hline 2013 & 378.862 & 44.690 & 44 & 3,80 & 0,012 & 4,38 & $3,24-5,92$ \\
\hline 2014 & 399.753 & 46.877 & 132 & 11,41 & 0,033 & 17,59 & $14,62-21,17$ \\
\hline 2015 & 404.385 & 11.565 & 278 & 24,03 & 0,056 & 83,07 & $70,86-97,39$ \\
\hline $\begin{array}{l}\text { Total/ } \\
\text { Mean }\end{array}$ & $356,736 *$ & 274.792 & 1157 & 100,0 & 0,033 & & \\
\hline
\end{tabular}

From the graph 3 seen the number of brain samples of various animal species examined from November 2008 - July 2015,) recorded 7,174 samples and 404 samples were FAT positive highest rabies occur in 2010. 


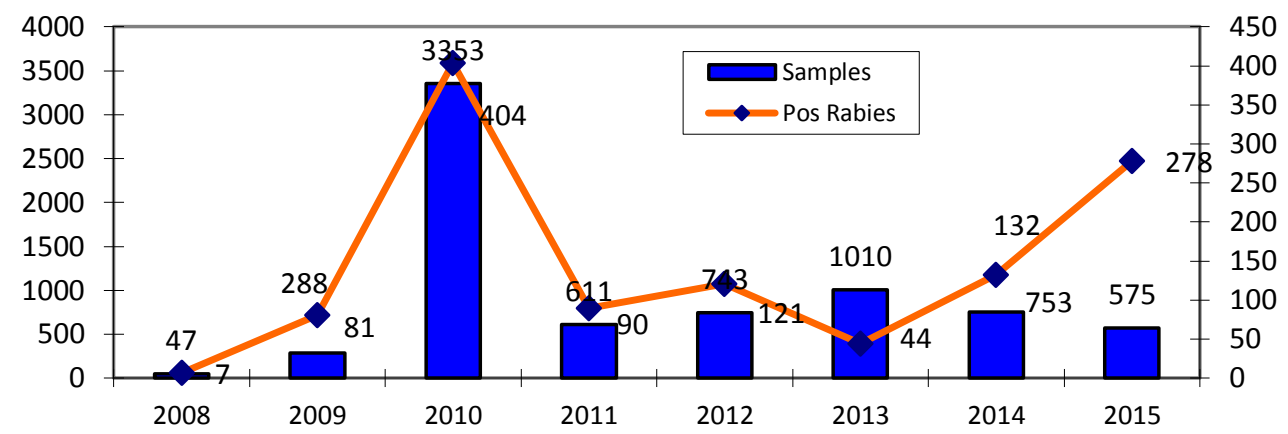

Graph 3. The frequency of cases of rabies in Bali

Distribution of samples positive for rabies in districts/municipalities in Bali showed highest in Bangli regency, 196 samples (Figure 4).

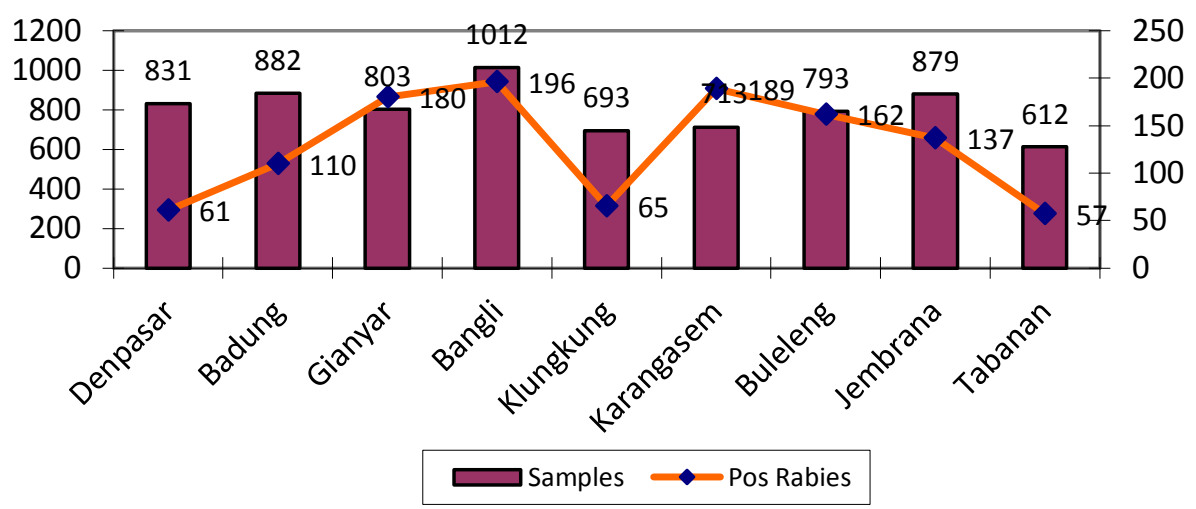

Graph 4. Distribution of Rabies positive, November-Juli 2015

Distribution of rabies in Bali shows the average prevalence of $16.1 \%$, the highest in Karangasem district (26.1\%), but the proportion of cases seen highest in Bangli district, 16.94\% (95\% CI 14,63- 19.25) (Table 3).

Table 3

The prevalence and proportion of positive rabies in Bali, 2008- July 2015

\begin{tabular}{llllll}
\hline $\begin{array}{l}\text { Districts/ } \\
\text { Municipality }\end{array}$ & $\begin{array}{l}\text { Total } \\
\text { samples }\end{array}$ & $\begin{array}{l}\text { Positive } \\
\text { rabies }\end{array}$ & Prevalence (\%) & $\begin{array}{l}\text { Positive } \\
\text { Proporsion }(\%)\end{array}$ & $\begin{array}{l}\text { 95\% Confidence } \\
\text { interval }(\mathrm{CI})\end{array}$ \\
\hline Denpasar & 831 & 61 & 7,3 & 5,27 & $3,75-6,79$ \\
Badung & 882 & 110 & 12,5 & 9,51 & $7,57-11,45$ \\
Gianyar & 803 & 180 & 22,4 & 15,56 & $13,01-18,01$ \\
Bangli & 1012 & 196 & 19,3 & 16,94 & $14,63-19,25$ \\
Klungkung & 693 & 65 & 9,3 & 5,62 & $3,91-7,33$ \\
Karangasem & 713 & 189 & 26,1 & 16,34 & $13,63-19,05$ \\
Buleleng & 793 & 162 & 21,8 & 14,0 & $11,5-16,49$ \\
Jembrana & 879 & 137 & 15,6 & 11,84 & $9,74-13,98$ \\
Tabanan & 612 & 57 & 9,3 & 4,93 & $3,21-6,65$ \\
Total & 7174 & 1157 & 16,1 & 100,0 & \\
\hline
\end{tabular}


Susceptible Animals

During an outbreak of rabies in Bali from 2008 until July 2015 has affected the various breeds of dogs, such as a local dog, Pekingese, and Siberian Husky. In addition, there is also in cats, Bali cattle, goats, and pigs Landrace Ottawa. The proportion of rabies in local dogs showed the highest, 98.44\% (95\% CI 97.8 to 99.08) (Table 4).

Table 4

Hospes tertular rabies di Bali, 2008 - Juli 2015

\begin{tabular}{llllll}
\hline Spesies animals & Total samples & $\begin{array}{l}\text { Rabies } \\
\text { Positive }\end{array}$ & $\begin{array}{l}\text { Prevalence } \\
(\%)\end{array}$ & $\begin{array}{l}\text { Proporsion } \\
\%\end{array}$ & $\begin{array}{l}\text { 95\% Confident } \\
\text { interval (CI) }\end{array}$ \\
\hline Local dogs & 7114 & 1139 & 16,0 & 98,44 & $97,8-99,08$ \\
Pekinges & 6 & 1 & 16,7 & 0,09 & $0,07-0,25$ \\
Siberian Huisky & 2 & 2 & 100,0 & 0,2 & $0,03-0,43$ \\
Local cats & 42 & 7 & 16,7 & 0,7 & $0,27-1,13$ \\
Bali cattles & 8 & 6 & 75,0 & 0,5 & $0,13-0,87$ \\
Goats & 1 & 1 & 100,0 & 0,09 & $0.07-0,25$ \\
Landrace pigs & 1 & 1 & 100,0 & 0,09 & $0,07-0,25$ \\
Total & 7174 & 1157 & 15,85 & 100,0 & \\
\hline
\end{tabular}

Sex and age of the dog

By sex and age group of dogs positive rabies shows the proportion of cases in male very significantly higher than female dogs $(\mathrm{P}<0.01)$, as well as by age group shows the proportion of 1-2 years of age showed the highest, 39, $85 \%$ (95\% CI 31, 92 to 48.36) (Table 5).

Table 5

Sex and age group of dogs infected with rabies

\begin{tabular}{lrrr}
\hline Sex & Total cases & Proportion & 5\% Confidence Interval (CI) \\
\hline Male & 53 & 80,30 & $69,02-88,20$ \\
Female & 13 & 19,70 & $11.75-30,93$ \\
& 66 & 100,0 & \\
Ages group & & & \\
$1-2$ months & 1 & 0,75 & $0,0001-0,456$ \\
3 -4 months & 15 & 11,28 & $6,85-17,88$ \\
$5-6$ months & 9 & 6,77 & $3,44-12,52$ \\
$7-8$ months & 1 & 0,75 & $0,0001-0,456$ \\
1 -2 years & 53 & 39,85 & $18,92-48,36$ \\
3 -4 years & 34 & 25,56 & $3,99-13,46$ \\
5 - 6 years & 10 & 7,52 & $3,99-13,44$ \\
7 >. Years & 10 & 7,52 & \\
\hline
\end{tabular}

\section{Season influence}

Based on predefined Denpasar BMKG dry season from April to November with rainfall $<50 \mathrm{~mm}$ and the rainy season months of December to March with rainfall> $50 \mathrm{~mm}$. The increasing cases of dog bites there seem to be the influence of the season. It is seen cases of dog bites are likely to increase following cycles of dogs mating and lambing season. First, the season dogs mating occurs towards the end of the rainy season in the last week of March, preceded period of estrus third week of February and then give birth in July near the top of the dry season in August, the next mating season in October and the season lambing in late March next year, continued mating season occurs in July and lambing season in October, so the next cycle. Since the outbreak of rabies, the number of positive cases of rabies is most prevalent during the dry season, except in 2010 looks at the most at the end of the rainy season into the dry season, there were 207 cases (Graph 5). 


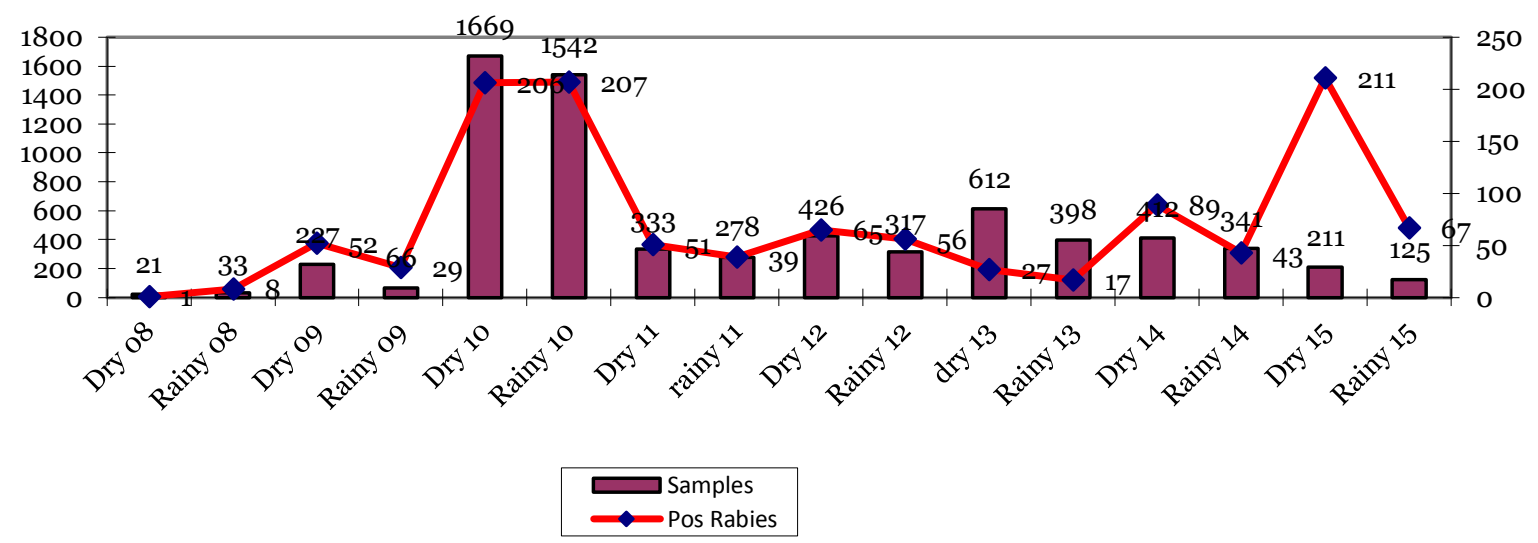

Graph 5. Positive rabies in the dry and rainy season

\section{Vectors role and mode of transmission of rabies}

There is no indication of the role of cats, monkeys, and bats in transmitting the rabies virus in Bali, as well as mechanical vectors of flies and mosquitoes. The rabies virus is only transmitted through the bites of dogs, cats, cows, goats, and pigs were detected positive for rabies as a result of dog bites.

\section{Discussion}

An outbreak of rabies in Bali as a result of the inclusion of a dog contracting rabies endemic areas. Various speculation is suspected the possibility of an escalation of bioterrorism by inserting the rabies virus form freeze-dried (freeze-dried) and then injected in dogs in Bali or put the dog illegally within the incubation period of rabies from infected areas, even though the way is full of risk for himself that included animal such as clinical symptoms will appear more quickly due to the stress of transportation from origin to Bali. Various allegations seem to be hard to prove, but can only be proven to reveal the phylogenetic origin and a close kinship of the rabies virus. Of several isolates of rabies virus Bali that was analyzed showed that the rabies virus Bali form clusters apart, but have a close kinship with the rabies virus Sulawesi, Kalimantan and Flores (Mahardika et al., 2014) and regional rabies Indonesia has a close kinship with the rabies virus China, Malaysia, Laos, and Thailand, but it is closest to the rabies virus China (Heru Susetya, 2008). Nonetheless still required further study to more virus isolates from all districts / municipalities in Bali from all time periods since the outbreak of rabies that can be ascertained the validity of homology or genetic distance of the closest in the cluster with the rest of the rabies virus Bali, in addition to ensuring may have been a mutation or genetic recombination into a variant virus or novel virus given the use of various strains of the vaccine virus and the number of dog bite cases positive for rabies without showing any clinical symptoms. What to watch for the early emergence of rabies in Bali peninsula and easy entry to Bali rabies an indication of the weak traffic surveillance of animal rabies from infected areas. Similarly, the absence of risk analysis since its inception as rabies-free area and is located between the area of contracting rabies. While Bali as an open area with land, sea and air implications for easy entry of dogs from infected areas, such as Java (West Java, Banten), Sumatra, Kalimantan, Sulawesi and Flores. Since the outbreak of rabies in Bali in 2008 which was originally confined to the southern peninsula of Bali, but then spread rapidly throughout the district/municipality

There is an increasing trend of dog bite cases infected with rabies, followed by increasing the number of samples positive for rabies in dogs proved that the implementation of the eradication of rabies in Bali is not maximized. Various factors, including the high population of dogs in the shelter dense population, the number of stray dogs or dogs that wild home and no vaccination coverage up to $100 \%$. During this limitation vaccination coverage is at least $70 \%$ so that the vaccinator officers if vaccination coverage has reached more than $70 \%$ or benchmark the average achievement of rabies vaccination coverage from 2009 to the current $80.9 \%$ is regarded as herd immunity against the entire dog population Bali. Though herd immunity against rabies is transmitted through the bite of an animal with 
rabies different from another infectious animal disease through direct contact, aerosol or via insect vectors. Therefore $19.1 \%$ unvaccinated dog population including high-risk populations, because they do not have a memory cell antibodies or immunity, will be easily infected with rabies, although there is the suggestion that the remaining unvaccinated dog population will die so that the remaining population is immune. But it must be understood if the entire population at high risk of contracting rabies during the incubation period until the clinical symptoms occur bites in humans and other animals, especially human rabies dog bites do not get immediate post-bite treatment by administering VAR certainly were a lot of deaths. Therefore, Bali as a rabies endemic areas with vaccination coverage is not $100 \%$ maximal no warranties of any person bitten by a dog would be safe from rabies so that the cost of controlling rabies in Bali becomes very expensive because every bite should be given VAR. Actually, there are classic excuse of not reaching vaccination coverage up to $100 \%$, because of the difficulty of catching the dog and many dogs home that wild, besides the limited number of vaccinators to reach all the population in 716 villages with thousands of banjo / hamlets and number of households per banjo / hamlet Average -rata having a dog is not even available dog population data are valid. While this is only based on the assumption that the target and the realization of the vaccination are not suitable. In the implementation of dog vaccination and elimination practiced during the anesthetic techniques and netting very helpful program to eradicate rabies. The most important to involve the community in each vaccination, such as forming a cadre vaccinator per village or Banjar and gives confidence and responsibility for the success of vaccination and dog population control in each environment will greatly help the success of the eradication of rabies in Bali.

The decline in the number of positive cases of rabies and the number of deaths significantly in the year 2013 should be used as an evaluation that the implementation of the eradication of rabies in Bali is correct, but since the launch of the new vaccine strain locally in July 2004 that its efficacy is not clear, especially security (safety) and potential virus vaccine should meet the standard test set (Aubert et al., 1996), if the virus the vaccine is unsafe and potential low can certainly occur a significant increase in the number of positive cases of rabies in animals, and the death toll is also rising, if not immediately get treatment after a dog bite by giving VAR. Indications are a visible number of positive cases of rabies in animals and the number of deaths in 2014 and 2015 increased significantly. Even the predicted number of canine rabies until the end of 2015 will continue to increase and exceed the number of positive cases of rabies in 2010. During an outbreak of rabies in Bali tends to be an increase in the number of cases of dog bites and rabies in dogs mating season (Malaga et al., 1979; Tepsumethanon et al., 1997) even after a dog birth and lactation. When dogs mating season, the female dog in estrus period secrete pheromones through saliva, urine, and stool as a sign of chemical information to the stud dog that can be detected by vemoronasal or organ Jacobso'n (Pageat \& Gaultier, 2003) which is located between the nose and mouth, Signals ready to marry the bitch informed to male dogs so many dogs adult males ready to marry came from various places and hang out with each other to show their existence, not infrequently, fights between dogs and if there is a dog infected with rabies in the incubation period, the same time there will be contagion rabies virus. It shows an adult male dogs of the age group between ages 1 to 2 years the greatest role in the transmission of rabies virus in Bali. Cycle mating and lambing seasons dogs tend to occur in the dry season (Stella Ejura Idachaba, 2009), when the lambing or lactating dogs aggressive nature to look to the higher nibble let alone a provocation. As it was reported that a dog infected with rabies tend to be higher in developing countries during the breeding season (Malaga et al., 1997) and the incubation period can excrete the virus. The amount of virus excreted in saliva is relatively high and lasts 7 to 14 days before clinical symptoms appear (Vaughn et al., 1963; Vaughn et al., 1965; Fukadu et al., 1982). Dogs infected with rabies generally will not survive more than 10 days after the symptoms appear (Veera Tepsumethanon et al., 2004). When symptoms of rabies appear, the dog looks nervous, confused, did not know his master and dog bite cases actually occur in the home environment itself before leaving the home dog to roam long distances could reach 1 to $5 \mathrm{~km}$. Not infrequently throughout the movement of the dog if there was provocation or movement then the dog would attack and bite. Various species of animals, such as cats, cows, goats and pigs victims of dog bites rabies. Pet animals are close to the environment of the rural population and are considered also provoke the dog when they are nearby. The majority of dog breeds that contracting is a dog local/village than purebred dogs as purebred dogs generally do not wild and have been vaccinated against rabies.

\section{Conclusion}

Provide a statement that what is expected, as stated in the "Introduction" chapter can ultimately result in "Results and Discussion" chapter, so there is compatibility. Moreover, it can also be added the prospect of the development of research results and application prospects of further studies into the next (based on result and discussion). 


\section{Acknowledgments}

The author express appreciation to, and acknowledgment of their collaborations in this studies. Thanks to the Head of Department of Animal Husbandry and Health of Bali Province, and Head of Unit Animal Health Laboratory, Province of Bali on cooperation and surveillance data rabies in Bali, as well as Head of BBVet Denpasar on the data results of laboratory tests. 


\section{References}

Altman, D. G. (1991). Statistics in medical journals: developments in the 1980s. Statistics in medicine, 10(12), 18971913.

Altman, D. G. (1998). Confidence intervals for the number needed to treat. Bmj, 317(7168), 1309-1312.

Alexander, D. J., Blancou, J., \& Truszczynski, M. (1996). Manual of standards for diagnostic test and vaccines. Srd ed, 161-169.

Cleaveland, S., Kaare, M., Knobel, D., \& Laurenson, M. K. (2006). Canine vaccination-providing broader benefits for disease control. Veterinary microbiology, 117(1), 43-50.

Coetzee, P., \& Nel, L. H. (2007). Emerging epidemic dog rabies in coastal South Africa: a molecular epidemiological analysis. Virus research, 126(1-2), 186-195.

Daly, L. E. (1998). Confidence limits made easy: interval estimation using a substitution method. American Journal of Epidemiology, 147(8), 783-790.

Fekadu, M., Shaddock, J. H., \& Baer, G. M. (1982). Excretion of rabies virus in the saliva of dogs. Journal of Infectious Diseases, 145(5), 715-719.

Flannigan, G., \& Dodman, N. H. (2001). Risk factors and behaviors associated with separation anxiety in dogs. Journal of the American Veterinary Medical Association, 219(4), 460-466.

Hosie, M. J., Addie, D., Belák, S., Boucraut-Baralon, C., Egberink, H., Frymus, T., ... \& Marsilio, F. (2009). Feline immunodeficiency. ABCD guidelines on prevention and management. Journal of Feline Medicine \& Surgery, 11(7), 575-584.

Wera, E. (2001). Epidemiologi Dan Usaha Pemberant Asan Penyakit Rabies Di Kabupaten Flores Timur Provinsi Nusa Tenggara Timur Periode Nopember 1997-April 2000 (Doctoral dissertation, Bogor Agricultural University (IPB)).

Ketut Santhia, A. P., Putra, A. A. G., Dibia, N., Mastra, K., Daniels, P., \& Lunt, R. Surveilans terhadap japanese encephalitis pada hewan sentinel.

Knobel, D. L., Cleaveland, S., Coleman, P. G., Fèvre, E. M., Meltzer, M. I., Miranda, M. E. G., ... \& Meslin, F. X. (2005). Re-evaluating the burden of rabies in Africa and Asia. Bulletin of the World health Organization, 83(5), 360-368.

Lindsay, S. R. (2001). Fears and phobias. Handbook of Applied Dog Behavior and Training: Etiology and Assessment of Behavior Problems, Volume 2, 69-92.

Madhusudana, S. N., \& Sukumaran, S. M. (2008). Antemortem diagnosis and prevention of human rabies. Annals of Indian Academy of Neurology, 11(1), 3.

Mahardika, G. N. K., Dibia, N., Budayanti, N. S., Susilawathi, N. M., Subrata, K., Darwinata, A. E., ... \& Sudewi, A. A. R. (2014). Phylogenetic analysis and victim contact tracing of rabies virus from humans and dogs in Bali, Indonesia. Epidemiology \& Infection, 142(6), 1146-1154.

Malaga, H., Nieto, E. L., \& Gambirazio, C. (1979). Canine rabies seasonality. International journal of epidemiology, 8(3), 243-246.

McElhinney, L. M., Fooks, A. R., \& Radford, A. D. (2008). Diagnostic tools for the detection of rabies virus. EJCAP, 18(3), 224-230.

McCrave, E. A. (1991). Diagnostic criteria for separation anxiety in the dog. Veterinary Clinics of North America: Small Animal Practice, 21(2), 247-255.

Meslin, F. X. (1997). Prospects for immunization against rabies in developing countries. Rabies control in Asia, 1518.

Nadin-Davis, S. A., Casey, G. A., \& Wandeler, A. I. (1994). A molecular epidemiological study of rabies virus in central Ontario and western Quebec. Journal of General Virology, 75(10), 2575-2583.

Pageat, P., \& Gaultier, E. (2003). Current research in canine and feline pheromones. Veterinary Clinics: Small Animal Practice, 33(2), 187-211.

Putra, A. A. G., Gunata, I. K., \& Asrama, I. G. (2011). Dog demography in Badung District, the province of Bali, and their significance to rabies control. Buletin Veteriner, Disease Investigation Center Denpasar, 23, 14-24.

Sudarshan, M. K., Madhusudana, S. N., Mahendra, B. J., Rao, N. S. N., Narayana, D. A., Rahman, S. A., ... \& Ravikumar, K. (2007). Assessing the burden of human rabies in India: results of a national multi-center epidemiological survey. International Journal of Infectious Diseases, 11(1), 29-35.

Idachaba, S. E. (2009). Status of canine vaccination and the prevalence of rabies in humans and dogs in Plateau State, Nigeria 1998-2007 (Doctoral dissertation, University of Pretoria).

Susetya, H., Naoto, I., Sugiyama, M., \& Minamoto, N. (2005). Genetic Analysis of Glycoprotein Gene of Indonesian Rabies Virus. Indonesian Journal of Biotechnology, 10(1). 
Mkhize, G. C., Ngoepe, E. C., Du Plessis, B. J., Reininghaus, B., \& Sabeta, C. T. (2010). Re-emergence of dog rabies in Mpumalanga province, South Africa. Vector-borne and Zoonotic Diseases, 10(9), 921-926.

Takeuchi, Y., Houpt, K. A., \& Scarlett, J. M. (2000). Evaluation of treatments for separation anxiety in dogs. Journal of the American Veterinary Medical Association, 217(3), 342-345.

Tepsumethanon, W., Polsuwan, C., Lumlertdaecha, B., Khawplod, P., Hemachudha, T., Chutivongse, S., ... \& Phanuphak, P. (1991). Immune response to rabies vaccine in Thai dogs: a preliminary report. Vaccine, 9(9), 627630.

Vaughn, J. B., Gerhardt, P., \& Paterson, J. C. S. (1963). Excretion of street rabies virus in saliva of cats. JAMA, 184(9), 705-708.

Vaughn, J. B., Gerhardt, P., \& Newell, K. W. (1965). Excretion of street rabies virus in saliva of dogs. J Am Med Assoc, 193(5), 113-118.

Tepsumethanon, V., Lumlertdacha, B., Mitmoonpitak, C., Sitprija, V., Meslin, F. X., \& Wilde, H. (2004). Survival of naturally infected rabid dogs and cats. Clinical infectious diseases, 39(2), 278-280.

Warrell, M. J., \& Warrell, D. A. (2004). Rabies and other lyssavirus diseases. The Lancet, 363(9413), 959-969.

Wells, D. L. (2004). A review of environmental enrichment for kennelled dogs, Canis familiaris. Applied Animal Behaviour Science, 85(3), 307-317.

Lindayani, L. R., Masri, F. A., Idul, R., \& Sawali, L. (2018). A metaphorical analysis of Kabhanti Modero to show Munanese social relations. International Journal of Linguistics, Literature and Culture (IJLLC), 4(2), 72-80.

Ogu, G. I., \& Orjiakor, P. I. (2017). Microbiological and Nutritional Qualities of Fermented Melon Seed Shells. International Journal of Life Sciences (IJLS), 1(2), 1-9.

Suarjana, N., Karmaya, I. N. M., Satriyasa, B. K., Pangkahila, J. A., \& Astuti, N. P. W. (2017). The Influence of Granting Ngor Eggplant (Solanium Indicum) Extract inhibiting of Spermatogenesis in Mice (Mus Musculus). International Journal of Health Sciences (IJHS), 1(2), 12-19. 